\title{
Diagnosis of the reading and interpretation of statistical graphs by undergraduate students from economic- administrative sciences programs at the University of \\ Guadalajara
}

Diagnóstico sobre la lectura e interpretación de gráficos estadísticos en estudiantes de licenciatura de ciencias económica-administrativas en la Universidad de Guadalajara

Diagnóstico na leitura e interpretação de gráficos estatísticos em alunos de graduação em ciências econômico-administrativas da Universidade de Guadalajara

Salvador Sandoval

Universidad de Guadalajara, Departamento de Métodos Cuantitativos, México salvador.sandoval@academicos.udg.mx https://orcid.org/0000-0001-9434-6536

Robert delMas University of Minnesota, Department of Educational Psychology, U.S.A delma001@umn.edu https://orcid.org/0000-0002-0210-6437

Pedro Celso-Arellano

Universidad de Guadalajara, Departamento de Métodos Cuantitativos, México pedro.celso@academicos.udg.mx https://orcid.org/0000-0003-3856-6344

Victor Gualajara

Universidad de Guadalajara, Departamento de Métodos Cuantitativos, México victor.gualajara@academicos.udg.mx https://orcid.org/0000-0002-5405-3779 
Semei Coronado*

Independent Consultant. U.S.A. semei.coronado@gmail.com https://orcid.org/0000-0002-7945-7155

* Corresponding Author.

\section{Abstract}

Recently, statistical reasoning has been of vital importance not only in quantitative analysis but also in the interpretation of graphs at all educational levels. There are students that can make calculations almost immediately but are not able to interpret or present their ideas graphically. In this way, the present study seeks to conduct a diagnostic of the problems that economic-administrative students have when reading and interpreting graphs in their statistics courses. For this, a Spanish version of the test Comprehensive Assessment of Outcomes in Statistics (CAOS) was administered. This instrument allows for the determination of reasoning applied to different types of statistical graphs and in some cases to determine what type of calculation is required to do it. The instrument was applied to 138 undergraduate students from the economic-administrative area of the University of Guadalajara during January-June 2018. The results show that a large percentage of students confuse a normal distribution with a uniform one and that they are unable to distinguish that a bias can be determined from the measures of central tendency and dispersion, as well as other statistical reasoning difficulties. This may be as a result of a deficiency that exists in statistical teaching, an insufficient mathematical preparation on the part of the students, among other factors.

Keywords: Graphical Representations, Histograms, Variability.

\section{Resumen}

Recientemente el razonamiento estadístico ha sido de vital importancia no solo en el análisis cuantitativo, sino también en la interpretación de gráficos a todos los niveles educativos. Existen estudiantes que pueden realizar distintos cálculos de manera casi inmediata, sin embargo, no pueden interpretar o exponer sus ideas en un grafico. De esta manera, el presente trabajo pretende realizar un diagnóstico de los problemas que tienen los alumnos de licenciaturas económico-administrativas para leer e interpretar gráficos en su curso de estadística. Para ello se aplicó una prueba en su versión en español de 
Comprehensive Assessment of Outcomes in Statistics (CAOS). Dicho instrumento permite determinar como interpreta su razonamiento sobre distintos tipos de gráficos estadísticos y en algunos casos determinar qué tipo de cálculo se requiere para ello. El instrumento se aplicó a una muestra de 138 estudiantes de licenciaturas del área económico-administrativas de la Universidad de Guadalajara durante el semestre de enero-junio del 2018. Los resultados muestran que un gran porcentaje de los alumnos confunden la distribución normal con una uniforme, no distinguen que un sesgo se puede determinar por sus medidas de tendencia central o dispersión, entre otras dificultades de razonamiento estadístico. Esto puede ser debido a la deficiencia que existe en la enseñanza de la estadística, una preparación matemática insuficiente de los estudiantes, entre otros factores.

Palabras claves: Representación gráfica, Histogramas, Variabilidad.

\section{Resumo}

Recentemente, o raciocínio estatístico tem sido de vital importância não apenas na análise quantitativa, mas também na interpretação de gráficos em todos os níveis educacionais. Existem alunos que podem realizar cálculos diferentes quase imediatamente, no entanto, eles não podem interpretar ou expressar suas ideias em um gráfico. Desta forma, o presente trabalho tem como objetivo fazer um diagnóstico dos problemas que os alunos dos cursos de graduação econômico-administrativos têm para ler e interpretar gráficos em seu curso de estatística. Para isso, foi aplicado um teste em sua versão em espanhol do Comprehensive Assessment of Outcomes in Statistics (CAOS). Este instrumento permite que você determine como você interpreta seu raciocínio em diferentes tipos de gráficos estatísticos e, em alguns casos, determina que tipo de cálculo é necessário para isso. O instrumento foi aplicado a uma amostra de 138 alunos de graduação da área econômico-administrativa da Universidade de Guadalajara durante o semestre de janeiro a junho de 2018. Os resultados mostram que grande parte dos alunos confunde distribuição normal com distribuição uniforme, eles não distinguem que um viés pode ser determinado por suas medidas de tendência central ou dispersão, entre outras dificuldades de raciocínio estatístico. Isso pode ser devido à deficiência que existe no ensino de estatística, preparação matemática insuficiente dos alunos, entre outros fatores.

Palavras-chave: Representação gráfica, Histogramas, Variabilidade. 


\section{Introduction}

Graphical representation dates back more than 200 years (Unwin, 2008) For example, (Wainer \& Spence, 2005) compiled the work of (Playfair, 1801) who represented data in graphical form. The discipline of statistics uses either real or hypothetical data which can be interpreted graphically (Cleveland, 1985; Tufte, 2001). In any branch of the sciences and, independent of the type of data used to produce it, the ability to read and interpret a graph is indispensable for both students, irrespective of the educational level at which they are studying, and researchers in the making (Glazer, 2011).

Interpreting and reading a graph requires knowledge of statistics, mathematics and real life. In this digital age, information is most often presented graphically (Susac, Bubic, Kazotti, Planinic, \& Palmovic, 2018). Newspapers, magazines, billboards, television, the internet and new research generally present results in graph form. Therefore, students should learn to read and interpret graphs based on real data to ensure that they are able to read and interpret a graph throughout their academic life (Monteiro \& Ainley, 2007).

The present study seeks to evaluate the difficulties students have with reading and interpreting graphs solely in the academic context. Various studies have identified problems that students at different educational levels have with reading and interpreting graphs (Arteaga, Batanero, Contreras, \& Cañadas, 2016; Carrión \& Espinel, 2006; delMas, Garfield, \& Ooms, 2005; Espinel, 2007; Monteiro \& Ainley, 2003; Nolan \& Perrett, 2016; Whitaker \& Jacobbe, 2017; Wu, 2004). A large-scale study by (delMas et al., 2005) found that high school and college students confuse bar graphs and time plots with histograms, incorrectly use the differences in bar heights in histograms as an indicator of variation, and sometimes incorrectly interpret the horizontal measurement scale as a time scale. Other studies (e.g., Bakker \& Gravemeijer, 2004; Ben-Zvi, 2004; Hammerman \& Rubin, 2004; Konold, 2003; Leavy, 2006; Makar \& Confrey, 2005; McClain, Cobb, \& Gravemeijer, 2000) have documented student difficulties with learning to reason about graphical representations of distributions: they focus on particular values such as high and low ones or outliers rather than view a distribution as an aggregate; they have difficulty coordinating ideas of center, spread, density and skewness; they tend to compare slices of data or points, rather than comparing entire entities, taking into consideration overall center and spread. 
Cooper and Shore (2008) found that students demonstrated several misunderstandings when judging center and variability of a distribution represented in a graph. Interviews with college students indicated that many incorrectly associated greater variability in the heights of bars in a histogram with greater variability in the distribution, or that only the range was used to compare the variability represented by two histograms. They report that some misunderstandings are related to students' inability to consider the characteristics of the data represented in a graph, or related to how to compute measures of center such as the mean and median. For example, when estimating the median for a histogram, some students found the midpoint of the values represented on the x-axis. Students also demonstrated difficulty using the relative frequencies of values represented in a histogram when estimating variability, which was also found by (delMas et al., 2005). In addition, Cooper (2018) found that college students have difficulty understanding the underlying structures of different types of graphs that use bars to represent frequency, often erroneously transferring correct conceptions of variability from one type of graph to another.

From the perspective of the authors of this study, few studies have been conducted in Mexico in this area. For example, (Dolores \& Cuevas, 2007) carried out a study with students in their last year of primary and secondary school in order to understand their errors in reading and interpreting a graph. Similarly, (Eudave Muñoz, 2009) studied the levels of comprehension of frequency tables and line graphs in students and adults, aged between 15 and 64 years of age. (Ruiz Lopez, 2015) analyzed methods used in third and sixth grade elementary school to teach students the production of bar charts and the interpretation of tables and graphs. Following this line of research, the present study seeks to identify the difficulties that students in the first year of their undergraduate degree in the Economic-Administrative sciences experience when reading and interpreting statistical graphs.

In various countries since the 1980s, statistical education has been systematically promoted at all educational levels, from elementary to post-secondary level through programs, such as the Schools Council Project on Statistical Education in England, or the Quantitative Literacy, Data Driven Curriculum Strand for High School Mathematics and the National Council of Teachers of Mathematics projects in the United States. These projects have incorporated general proposals for statistical education (Cuevas \& Ibañez, 2008). 
Recently, the International Statistical Literacy Project, an ongoing global endeavor, was established with the fundamental objective of generating educational proposals and cutting edge research in the area of statistics (Sánchez, 2010). It should be noted that significant national endeavors are being conducted in this field in such countries as Chile, Argentina, China, Australia and New Zealand. These are countries which have strongly promoted statistical education, incorporating the latest advances in the area into their national curricula.

In Mexico, the Mexican Statistics Association supports the Red de Investigación y Educación en Probabilidad y Estadística (RIEPE, or Network for Research and Education in Probability and Statistics), which is responsible for disseminating and analyzing academic approaches and research conclusions in the area of statistical education. RIEPE is also charged with coordinating professors, researchers and national collegiate bodies in order to identify the main areas of opportunity for statistical research and education in the country. It seeks to encourage joint work with international academic institutions in order to establish a common agenda that promotes new developments and research in statistical education (RIEPE, 2012).

At the University of Guadalajara, the Centro Universitario de Ciencias Económico Administrativas (CUCEA, or University Center for the EconomicAdministrative Sciences) offers 16 undergraduate degree programs in the areas of economics and business. The Statistics I course is taught to all CUCEA undergraduate students, with its thematic content including basic concepts from descriptive statistics which cover graphic representation and basic probability. Per semester, the Statistics I course is taken by approximately 214 students distributed across 10 sections taught by 7 professors. The Statistics I curriculum is updated periodically by the Academy of Statistics, which forms part of the CUCEA's Department of Quantitative Methods, with the most recent update carried out in 2016. Since 2005 (Del Toro \& Ochoa, 2010) a departmental exam comprising 10 multiple choice questions designed by a commission of professors from the Academy of Statistics, has been applied to all students taking the course. The average grade is $50 \%$ for the exam.

In order to promote significant and competitive learning in the area of statistics, the CUCEA, through its Department of Quantitative Methods and in coordination with the Academy of Statistics, has organized the annual Statistics I Tournament since 2006, in which students enrolled in the Statistics I course are free to take part. The average Statistics I grade for those competing in the tournament is also around 50\%. In 2017, 


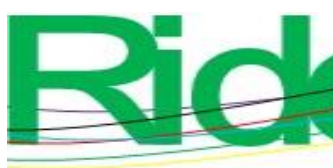

(Coronado, Sandoval, Celso, \& Torres, 2018a, 2018b) analyzed the results of the tournament, applying Rasch logistical models with the objective of determining whether this academic event effectively fosters an elevated level of statistical learning and performance and promotes competition among students. Only $13 \%$ of the students in the Statistics I competition demonstrated an acceptable level of statistical knowledge. However, the 20-item multiple choice test used in the tournament did not include items to measure student understanding of graphs. The purpose of the current study is to determine the ability of students who completed the Statistics I course to understand and interpret graphical representations in order to guide revision of the course curriculum, as well as the preparation of course instructors.

\section{Method}

A Spanish version of the CAOS exam, a validated and calibrated measurement instrument designed for students who have previously taken a basic statistics course at the undergraduate level, was administered to measure CUCEA undergraduate students' comprehension of histograms (ARTIST, 2006). The exam was designed to evaluate the statistical thinking of undergraduate students who have taken a statistics course, and prioritizes their conceptual comprehension and reasoning of the statistical content, in contrast to the mechanical calculation of formulas and procedures (delMas, Garfield, Ooms, \& Chance, 2007). The CAOS test comprises 40 questions, with between 2 and 5 multiple choice answer options for each. A subset of 11 CAOS questions that assess students' comprehension and graphical reasoning as taught in Statistics I were selected. The assessed learning objective identified by (delMas et al., 2007) for each of the 11 CAOS items can be found in Table 2.

A population of 214 students that took Statistics 1 in January-July 2018 was asked to complete the $11 \mathrm{CAOS}$ items at the end of the semester. Of the total population, 138 did so voluntarily and anonymously, achieving a high $64.5 \%$ participation rate. A sample size of 138 is estimated to produce a 5\% margin of error for estimating a $95 \%$ confidence interval for a population proportion, which represents a reasonable level of precision. Of the 138 students in the sample, students from all seven professors who taught the class were included. The answers were coded dichotomously, where 1 was given for a correct response and 0 for an incorrect one. 


\section{Result and discussion}

Table 1 presents the descriptive statistics from the database compiled for the exam applied in the present research. On a scale of 0 to 11 , the minimum value obtained was 3 and the maximum was 10, with no student answering all eleven questions correctly. The average score was 4.54, while the median and the mode were equal, with a value of 4 . The distribution of the data is asymmetric and positively skewed. This shows that a majority of students scored below the average and that the distribution is leptokurtic, given that there is a large amount of data around the median. It can be seen in Figure 1 that $83 \%$ of the students answered less than half of the items correctly.

Table 1. Descriptive Statistics for Percent Correct on the 11 Selected CAOS Items ( $\mathrm{n}=$ 138)

\begin{tabular}{|l|r|}
\hline Statistics & Value \\
\hline Mean & 4.54 \\
\hline Median & 4.00 \\
\hline Mode & 4.00 \\
\hline Standard deviation & 1.40 \\
\hline Variance of the sample & 1.96 \\
\hline Kurtosis & 1.84 \\
\hline Asymmetry coefficient & 1.25 \\
\hline Minimum & 3.00 \\
\hline Maximum & 10.00 \\
\hline
\end{tabular}

Source: Prepared by the author based on the sample 


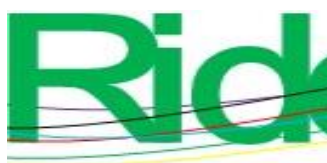

Figure 1. Distribution of Percent Correct on the 11 Selected CAOS Items $(n=138)$.

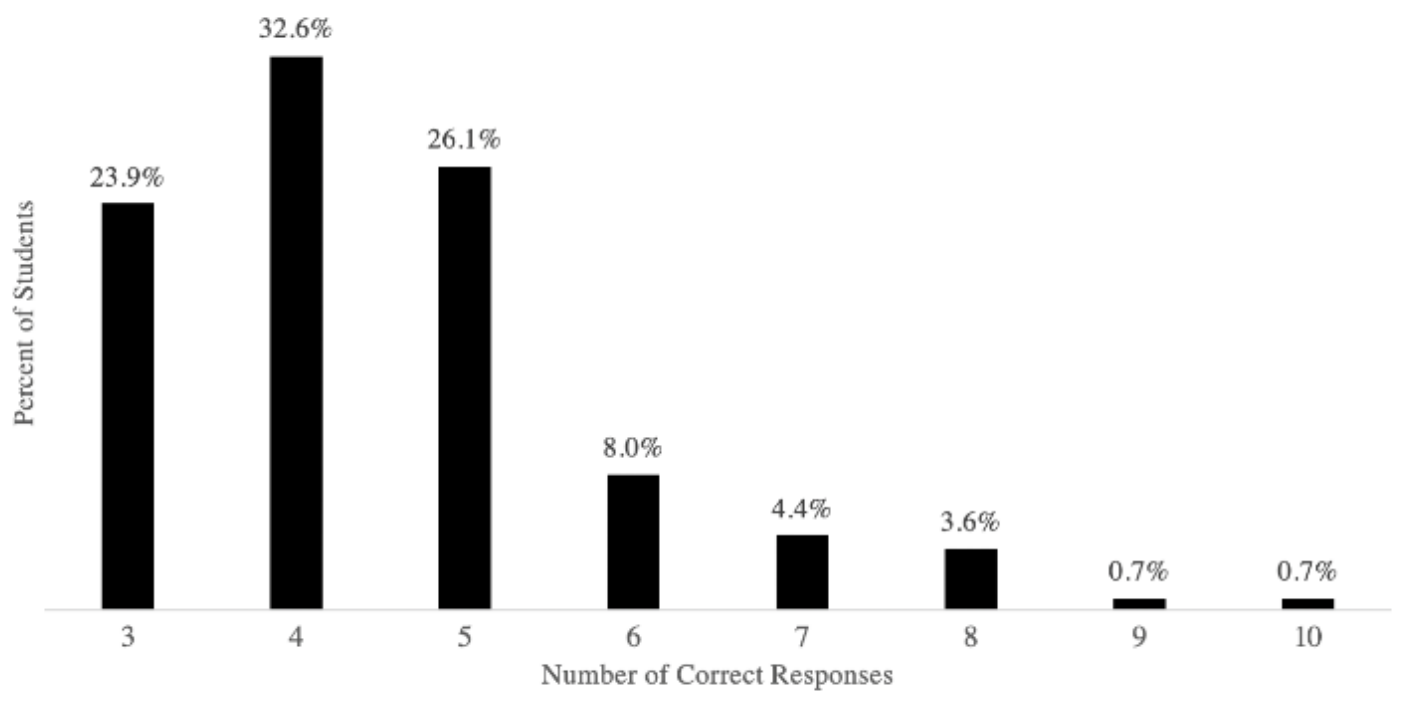

Source: Prepared by the author based on the sample

Table 2 presents the percentage of students who selected each response option for each item. Less than half of the students could match the description of a variable to an appropriate histogram (Items 2, 3 and 4). Only 37\% of the students were able to recognize a variable description for a bell-shaped distribution (Item 3), with the majority selecting a positively skewed or uniform distribution. Similarly, only $22 \%$ of the students correctly identified the histogram for the description of a variable with a uniform distribution (Item 4) compared to the majority who confused it with either a positively skewed or bellshaped distribution. Less than a third of the students could match a histogram to the description of a variable with a negative skewness (Item 2), with the majority selecting a histogram for a uniform distribution. Related to the Item 2 responses, only $37 \%$ demonstrated an understanding that the median being noticeably larger than the mean is indicative of a negatively skewed distribution (Item 11). Thus, many students demonstrated a clear issue with inability to between different types of distribution.

Only $52 \%$ of students selected a complete description of a graph (Item 1) and only $4 \%$ of students chose the correct response for Item 5, which asked them to identify a graph that represents the distribution, central tendency and dispersion of a variable. Students were more likely to choose one of the three case-value plots, especially one artificially shaped like a normal distribution (43\%). This may indicate a preference for symmetric, bell-shaped distributions and a lack of understanding that a graphic representation for the distribution of a variable must represent the shape, central tendency, 
and dispersion of the variable. It can be inferred from students' responses to the first five items that they are not familiar with different types of skewness and graph shapes, nor their relationship with central tendency and dispersion measures.

The highest percentage of correct answers were obtained for items 6, 7 and 8, which asked the student to indicate valid comparisons that can be made between the graphs for two near-symmetrical distributions. More than $80 \%$ of the students knew that the average could be used to compare two distributions (Item 7), 59\% demonstrated an ability to consider each distribution as an aggregate and not focus on individual cases (Item 6), and 59\% understood that sample sizes did not need to be equal to compare distributions (Item 8). This may show that the students are more familiar with symmetrical distributions. However, many students indicated it was valid to use special cases in each distribution to make a comparison, or that the sample sizes must be equal in order to make a comparison, even when the sample sizes are large.

Items 9 and 10 presented five different types of graphs in order to assess the students' interpretation of variation, specifically standard deviation, which they confused with the shape of the distribution of data and the degree to which the values diverge compared to the average. It is interesting to note that for Item 9, 44\% of the students associated a low value for standard deviation with a uniform distribution, compared to $30 \%$ who correctly related it to a bell curve distribution. This may indicate that many students associate the standard deviation with the variation in bar heights in a histogram and not with the dispersion of the variable. For Item 10, 39\% of the students did associate a larger standard deviation with a distribution in which the majority of the data is more distant from the arithmetic mean. However, $45 \%$ of the students chose one of the bellshaped distributions, possibly indicating a preference for a distribution that appears to be normally distributed, and not demonstrating an understanding that a uniform distribution over a similar range has a greater spread in data than a bell-shaped distribution.

Finally, Item 11 presented a table with descriptive statistics for a variable (mean, median, standard deviation, minimum, and maximum) and three types of graphs (bellshaped, negatively skewed, and positively skewed), and required the students to choose which graph best fits the statistics presented. Thus, despite the fact that the skewness of the distribution can be identified from the statistics (the mean is noticeably less than the median), close to $60 \%$ of the students associated them with the near-symmetrical shape. Thus, the students do not appear to be able to interpret a graph when it does not have a symmetrical shape. 
The results show that many students in undergraduate programs in the EconomicAdministrative sciences experience the following problems in reading and interpreting a bar chart or histogram: they confuse the shape of distribution from a data set; they do not know how to identify small or large standard deviation from a graph; and they can neither clearly identify skewed distributions nor relate them to their central tendency and dispersion measures. On the other hand, many students do make satisfactory interpretations when asked to compare symmetrical graphs with different arithmetic means and standard deviations; moreover, when presented with symmetrical distribution, they do satisfactorily describe both the central tendency and dispersion measures, as well as atypical values.

These results may be due to various probable causes, such as students not being taught the different forms of data distribution or their relationship with central tendency and dispersion measures and reveal that more emphasis may be placed on symmetrical than on asymmetrical distributions. Another cause could be the lack of teacher training in the area of graphical representation, which may be explained by the different types of pedagogical preparation of those teaching the statistics courses. 
Table 2. Percent of Students Who Chose Each Response Option for Each CAOS Item

(correct response is in bold type)

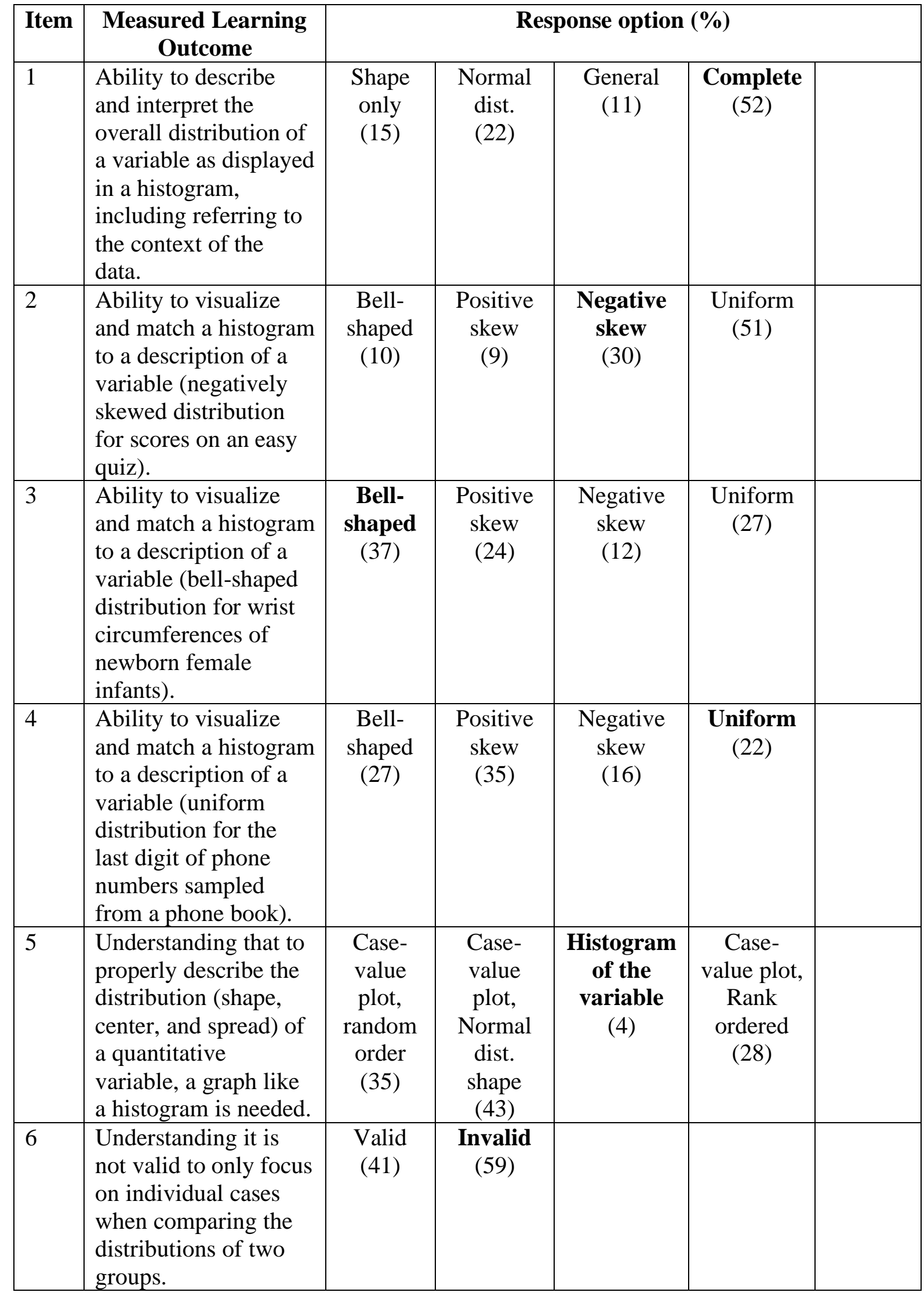




\begin{tabular}{|c|c|c|c|c|c|c|}
\hline 7 & $\begin{array}{l}\text { Understanding that } \\
\text { considering the } \\
\text { difference between } \\
\text { the means of } \\
\text { distributions for two } \\
\text { groups is valid when } \\
\text { the distributions are } \\
\text { fairly symmetric. }\end{array}$ & $\begin{array}{c}\text { Valid } \\
(82)\end{array}$ & $\begin{array}{c}\text { Invalid } \\
\text { (18) }\end{array}$ & & & \\
\hline 8 & $\begin{array}{l}\text { Understanding that } \\
\text { comparing two groups } \\
\text { does not require equal } \\
\text { sample sizes in each } \\
\text { group, especially if } \\
\text { both sets of data are } \\
\text { large. }\end{array}$ & $\begin{array}{c}\text { Valid } \\
\text { (41) }\end{array}$ & $\begin{array}{l}\text { Invalid } \\
\text { (59) }\end{array}$ & & & \\
\hline 9 & $\begin{array}{l}\text { Ability to correctly } \\
\text { estimate and compare } \\
\text { standard deviations } \\
\text { for different } \\
\text { histograms. } \\
\text { Understands lowest } \\
\text { standard deviation } \\
\text { would be for a graph } \\
\text { with the least spread } \\
\text { (typically) away from } \\
\text { the center. }\end{array}$ & $\begin{array}{c}\text { Bell- } \\
\text { shaped, } \\
\text { small sd } \\
(30)\end{array}$ & $\begin{array}{c}\text { U-shaped } \\
\text { (15) }\end{array}$ & $\begin{array}{l}\text { Uniform } \\
\text { (44) }\end{array}$ & $\begin{array}{l}\text { Bell- } \\
\text { shaped, } \\
\text { medium } \\
\text { sd } \\
(9)\end{array}$ & $\begin{array}{l}\text { Bell- } \\
\text { shaped, } \\
\text { large sd } \\
\text { (2) }\end{array}$ \\
\hline 10 & $\begin{array}{l}\text { Ability to correctly } \\
\text { estimate standard } \\
\text { deviations for } \\
\text { different histograms. } \\
\text { Understands highest } \\
\text { standard deviation } \\
\text { would be for a graph } \\
\text { with the most spread } \\
\text { (typically) away from } \\
\text { the center. }\end{array}$ & $\begin{array}{c}\text { Bell- } \\
\text { shaped, } \\
\text { small sd } \\
(23)\end{array}$ & $\begin{array}{c}\text { U- } \\
\text { shaped } \\
(39)\end{array}$ & $\begin{array}{l}\text { Uniform } \\
\text { (16) }\end{array}$ & $\begin{array}{l}\text { Bell- } \\
\text { shaped, } \\
\text { medium } \\
\text { sd } \\
(9)\end{array}$ & $\begin{array}{l}\text { Bell- } \\
\text { shaped, } \\
\text { large sd } \\
(13)\end{array}$ \\
\hline 11 & $\begin{array}{l}\text { Understanding that a } \\
\text { distribution with the } \\
\text { median larger than } \\
\text { mean is most likely } \\
\text { skewed to the left. }\end{array}$ & $\begin{array}{c}\text { Bell- } \\
\text { shaped } \\
(59)\end{array}$ & $\begin{array}{c}\text { Negative } \\
\text { skew } \\
(37)\end{array}$ & $\begin{array}{c}\text { Positive } \\
\text { skew } \\
(4)\end{array}$ & & \\
\hline
\end{tabular}

Source: Prepared by the author based on the sample 


\section{Conclusion}

In this study, the CAOS test was applied to undergraduate students who had taken a descriptive statistics course to assess their statistical thinking. The results show that a high percentage of students had problems recognizing what kind of distribution they were analyzing. Also, they were confused with how to calculate the skew with measures of central tendency or dispersion. There could be another factor that affects their performance in statistical thinking. For instance, there could be deficiencies in the way they are taught statistics.

Therefore, it is recommended that course instructors receive pedagogical training in research-based teaching methods that have been shown to develop students' ability to understand and reason with graphical representations. For example, methods developed by Bakker (2004) that have students go through a series of exercises where they "grow a sample" have been shown to promote aggregate and distributional thinking in students. Cooper and Shore (2010) have suggested visual aids that may help students visualize and understand variability as it is represented in histograms and value bar charts. Garfield \& Ben-Zvi (2005) provide a conceptual model for developing students' reasoning about variability. Two components of the model related to understanding variability represented by graphic representations (describing and representing variability; recognizing variability in special types of distributions) provide instructional goals for teaching and assessment. A teaching experiment conducted with preservice teachers by Leavy (2006) indicated that students who used graphic representations, in addition to summary statistics, to compare distributions of data demonstrated increased attention to global trends in distributions and more success in communicating the use of graphical representations towards the end of a 15-week course. Hopefully, students' understanding of and reasoning about graphical representations can be developed through better preparation of course instructors.

Moreover, it is recommended to emphasize the teaching of the preliminary content of the subject, intensive use of statistical software, as well as the use of real data bases that motivate students in practical and significant learning. As a possible extension of this work, to be analyzed in the future, is the reading and interpretation of statistical graphs in the classroom, teaching methodologies, the teaching itself and the academic curriculum to determine whether one of these factors is failing or a combination of multiple factors. At the same time, a comparative study could be done of graph interpretation between students of an economicadministrative background and students from other undergraduate majors or other institutions of higher education. 


\section{References}

Arteaga, P., Batanero, C., Contreras, J. M., \& Cañadas, G. (2016). Evaluación de errores en la construcción de gráficos estadísticos elementales por futuros profesores. Revista Latinoamericana de Investigación En Matemática Educativa, 19(1), 15-40. https://doi.org/10.12802/relime.13.1911

ARTIST. (2006). Retrieved February 1, 2019, from https://apps3.cehd.umn.edu/artist/

Bakker, A. (2004). Reasoning about shape as a pattern in variability. Statistics Education Research Journal, 3(2), 64-83.

Bakker, A., \& Gravemeijer, K. (2004). Learning to reason about distribution. In D. Ben-Zvi \& J. B. Garfield (Eds.), The challenge of developing statistical reasoning, literacy, and thinking (pp. 147-168). Dordrecht, Netherlands: Kluwer Academic Publisher.

Ben-Zvi, D. (2004). Reasoning about data analysis. In D. Ben-Zvi \& J. B. Garfield (Eds.), The challenge of developing statistical reasoning, literacy and thinking (pp. 121-146). Dordrecht, Netherlands: Kluwer Academic Publisher.

Carrión, J. C., \& Espinel, M. C. (2006). An investigations about translation and interpretation of statistical graphs and tables by students of primary education. In A. Rossman \& B. Chance (Ed.), Proceedings of the Seventh International Conference on Teaching Statistics. Salvador, Brasil: International Statistical Institute.

Cleveland, W. S. (1985). The elements of graphing data. The Elements of Graphing Data, 323. https://doi.org/10.1017/CBO9781107415324.004

Cooper, L. L. (2018). Assessing students' understanding of variability in graphical representations that share the common attribute of bars. Journal of Statistics Education, 26(2), 110-124. https://doi.org/10.1080/10691898.2018.1473060

Cooper, L. L., \& Shore, F. S. (2008). Students' misconceptions in interpreting center and variability of data represented via histograms and stem-and-leaf plots. Journal of Statistics Education, 16(2). https://doi.org/10.1080/10691898.2008.11889559

Cooper, L. L., \& Shore, F. S. (2010). The effects of data and graph type on concepts and visualizations of variability. Journal of Statistics Education, 18(2). https://doi.org/10.1080/10691898.2010.11889487

Coronado, S., Sandoval, S., Celso, P. L., \& Torres, A. (2018a). Analysis of competitive learning at university level in Mexico via item response theory. Mediterranean Journal of Social Sciences, 9(4), 215-223. https://doi.org/10.2478/mjss-2018-0130 


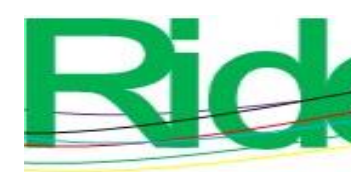

Coronado, S., Sandoval, S., Celso, P. L., \& Torres, A. (2018b). Competitive learning using a three-parameter logistic model. European Journal of Contemporary Education, 7(3), 448-457. https://doi.org/10.13187/ejced.2018.3.448

Cuevas, J., \& Ibañez, C. (2008). Estándares en educación estadística: necesidad de conocer la base teórica y empírica que los sustentan. Revista Iberoamericana de Educación Matemática, 15, 33-45.

Del Toro, H. L., \& Ochoa, M. B. (2010). Exámenes departamentales en el cucea: el caso del departamento de métodos cuantitativos. XIV Congreso Internacional de Investigación En Ciencias Administrativas, 1-16. Monterrey, Mexico.

delMas, R., Garfield, J., \& Ooms, A. (2005). Using assessment items to study students' difficulty reading and interpreting graphical representations of distributions. Proceedings of the Fourth International Research Forum on Statistical Reasoning, Literacy, and Reasoning, 17. Auckland, New Zealand: K. Makar.

delMas, R., Garfield, J., Ooms, A., \& Chance, B. (2007). Assessing students' conceptual understanding after a first course in statistics. Statistics Education Research Journal, 6(2), 28-58. https://doi.org/10.1016/j.brat.2010.07.005

Dolores, C., \& Cuevas, I. (2007). Lectura e interpretación de gráficas. Revista Latinoamericana de Investigación En Matemática Educativa, 10(1), 69-96.

Espinel, M. C. (2007). Construcción y razonamiento de gráficos estadísticos en la formación de profesores. In M. Camacho, P. Flores, \& M. P. Bolea (Eds.), Investigación en educación matemática (pp. 99-120). Retrieved from http://funes.uniandes.edu.co/1277/1/Espinel2008Construccion_SEIEM_99.pdf

Eudave Muñoz, D. (2009). Niveles de comprensión de información y gráficas estadísticas en estudiantes de centros de educación básica para jóvenes y adultos de México. Educación Matemática, 21(2), 5-37.

Garfield, J., \& Ben-Zvi, D. (2005). A framework for teaching and assessing reasoning about variability. Statistics Education Research Journal, 4(1), 92-99.

Glazer, N. (2011). Challenges with graph interpretation: A review of the literature. Studies in Science Education, 47(2), 183-210. https://doi.org/10.1080/03057267.2011.605307

Hammerman, J. K., \& Rubin, A. (2004). Strategies for managing statistical complexity with new software tools. Statistics Education Research Journal, 3(2), 17-41.

Konold, C. (2003). Reasoning about data. In J. Kilpatrick, W. G. Martin, \& D. Schifter (Eds.), A research companion to principles and standards for school mathematics (pp. 193215). Reston, VA: National Council of Teachers of Mathematics. 


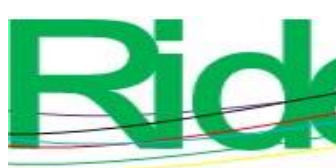

Leavy, A. M. (2006). Using data comparison to support a focus on distribution: Examining preservice teachers' understandings of distribution when engaged in statistical inquiry. Statistics Education Research Journal, 5(2), 89-114.

Makar, K., \& Confrey, J. (2005). "Variation-Talk": Articulating meaning in statistics. Statistics Education Research Journal, 4(1), 27-54.

McClain, K., Cobb, P., \& Gravemeijer, K. (2000). Supporting students' ways of reasoning about data. In M. Burke \& F. Curcio (Eds.), Learning mathematics for a new century, 2000 yearbook. Reston, VA: National Council of Teachers of Mathematics.

Monteiro, C., \& Ainley, J. (2003). Interpretation of Graphs: Reading Through the Data. Proceedings of British Society for Research into Learning Mathematics, 23(3), 31-36.

Monteiro, C., \& Ainley, J. (2007). Investigating the interpretation of media graphs among student teachers. International Electronic Journal Mathematics Education, 2(3), 187207. Retrieved from http://www.iejme.com/download/investigating-the-interpretationof-media-graphs-among-student-teachers.pdf

Nolan, D., \& Perrett, J. (2016). Teaching and Learning Data Visualization: Ideas and Assignments. American 260-269. https://doi.org/10.1080/00031305.2015.1123651

Playfair, W. (1801). The commercial and political atlas, representing, by means of stained copper-plate charts, the progress of the commerce, revenues, expenditure, and debts of England, during the whole of the eighteenth century. London: Wallis.

RIEPE. (2012). Retrieved February 10, 2019, from Red de Investigación y Educación en Probabilidad y Estadística website: http://amestad.mx/red

Ruiz Lopez, N. (2015). La enseñanza de la estadística en la educación primaria en américa latina. REICE. Revista Iberoamericana Sobre Calidad, Eficancia y Cambio En Educación., 13(1), 103-121. Retrieved from www.rinace.net/reice/

Sánchez, J. (2010). International statistical literacy project. Retrieved February 5, 2019, from http://www.stat.fi/org/tilastokeskus/flyer.pdf

Susac, A., Bubic, A., Kazotti, E., Planinic, M., \& Palmovic, M. (2018). Student understanding of graph slope and area under a graph: A comparison of physics and nonphysics students. Physical Review Physics Education Research, 14(2), 020109. https://doi.org/10.1103/PhysRevPhysEducRes.14.020109

Tufte, E. R. (2001). The visual display of quantitative information (Second). https://doi.org/10.1119/1.14057 
Unwin, A. (2008). Handbook of Data Visualization. In C. Chen, W. Härdle, \& A. Unwin (Eds.), Handbook of Data Visualization. https://doi.org/10.1007/978-3-540-33037-0

Wainer, H., \& Spence, I. (2005). Playfair's commercial and political atlas and statistical breviary. New York, NY, USA: Cambridge University Press.

Whitaker, D., \& Jacobbe, T. (2017). Students' understanding of bar graphs and histograms: Results from the LOCUS assessments. Journal of Statistics Education, 25(2), 90-102. https://doi.org/10.1080/10691898.2017.1321974

$\mathrm{Wu}, \mathrm{Y}$. (2004). Singapore secondary school students' understanding of statistical graphs. Proceedings of the 10th International Congress on Mathematical Education, 1-7. Copenhagen, Denmark. 


\begin{tabular}{|c|c|}
\hline Rol de Contribución & Autor (es) \\
\hline Conceptualización & Semei Coronado \\
\hline Metodología & Robert delMAs \\
\hline Software & No aplica \\
\hline Validación & $\begin{array}{l}\text { Semei Coronado (igual), Salvador Sandoval (igual), Pedro } \\
\text { Celso-Arellano (igual), Victor Gualajara (igual), Robert } \\
\text { delMas (igual). }\end{array}$ \\
\hline Análisis Formal & $\begin{array}{l}\text { Semei Coronado (igual), Salvador Sandoval (igual), Pedro } \\
\text { Celso-Arellano (igual), Victor Gualajara (igual). }\end{array}$ \\
\hline Investigación & $\begin{array}{l}\text { Semei Coronado (igual), Salvador Sandoval (igual), Pedro } \\
\text { Celso-Arellano (igual), Victor Gualajara (igual), Robert } \\
\text { delMas (igual). }\end{array}$ \\
\hline Recursos & $\begin{array}{l}\text { Semei Coronado (igual), Salvador Sandoval (igual), Pedro } \\
\text { Celso-Arellano (igual), Victor Gualajara (igual), Robert } \\
\text { delMas (igual). }\end{array}$ \\
\hline Curación de datos & $\begin{array}{l}\text { Semei Coronado (igual), Salvador Sandoval (igual), Pedro } \\
\text { Celso-Arellano (igual), Victor Gualajara (igual). }\end{array}$ \\
\hline $\begin{array}{l}\text { Escritura - Preparación del } \\
\text { borrador original }\end{array}$ & $\begin{array}{l}\text { Semei Coronado (igual), Salvador Sandoval (igual), Pedro } \\
\text { Celso-Arellano (igual), Victor Gualajara (igual), Robert } \\
\text { delMas (igual). }\end{array}$ \\
\hline $\begin{array}{l}\text { Escritura - Revisión y } \\
\text { edición }\end{array}$ & $\begin{array}{l}\text { Semei Coronado (igual), Salvador Sandoval (principal), } \\
\text { Pedro Celso-Arellano (igual), Victor Gualajara (igual), } \\
\text { Robert delMas (igual). }\end{array}$ \\
\hline Visualización & $\begin{array}{l}\text { Semei Coronado (igual), Salvador Sandoval (principal), } \\
\text { Pedro Celso-Arellano (igual), Victor Gualajara (igual), } \\
\text { Robert delMas (igual). }\end{array}$ \\
\hline Supervisión & $\begin{array}{l}\text { Semei Coronado (igual), Salvador Sandoval (principal), } \\
\text { Pedro Celso-Arellano (igual), Victor Gualajara (igual). }\end{array}$ \\
\hline $\begin{array}{l}\text { Administración de } \\
\text { Proyectos }\end{array}$ & Semei Coronado (igual), Salvador Sandoval (igual). \\
\hline Adquisición de fondos & No aplica \\
\hline
\end{tabular}

